\title{
Research on the Educational Environment for Households
}

\author{
Andrey Kalsin \\ State Federal-Funded Educational Institution of Higher Vocational Education Yaroslavl State Pedagogical University named after \\ K.D. Ushinsky \\ Yaroslavl, Russia
}

\author{
Dmitry Vakhrushev \\ State Federal-Funded Educational Institution of Higher \\ Vocational Education Yaroslavl State University named \\ after P.G. Demidov \\ Yaroslavl, Russia
}

\author{
Oleg Dubinin \\ State Federal-Funded Educational Institution of Higher \\ Vocational Education Yaroslavl State Pedagogical \\ University named after K.D. Ushinsky \\ Yaroslavl, Russia
}

\begin{abstract}
This article analyses the educational environment for households. The basic needs of a household include low-interest loans, available grants, tax credits, purchasing of new equipment at moderate prices and acquiring of land. Household economic interests will fall into two parts: satisfaction of the needs of the household members; and support of the household operation as an economic unit. Educational environment as an environment formed like a system which enables interaction between subjects of the educational process and the external environment.
\end{abstract}

Keywords-peasant households; farm households; agricultural sector; educational environment

\section{INTRODUCTION}

The research rationale is determined by several fundamental aspects.

Firstly, the crisis in the agricultural sector of the economy has proven that households are competitive and can effectively develop as individual production with absolute control and maximum responsibility.

Secondly, the necessity to survive in difficult economic conditions makes households look for appropriate financing sources and ways of their effective use.

Thirdly, another significant factor defining the prospects for the development of the household sector is the priority extension in the social and economic policy of the government which is aimed at supporting individual producers.

Fourthly, the existing contradictions between household needs and the financial resources of the state are based on the imperfect structure of financial relations in the economy as a whole. There is a long-standing need for elaborating such a mechanism of social and economic household functioning which on the one hand could ensure their sustainable and stable development and on the other hand could guarantee a steady flow of state revenues and the whole range of the public services.

In addition, we should remember that the group of households comprises households which differ in their nature

- peasant households are based on the labour of the family members and ownership; their goal is to satisfy

- the family needs for food, household goods and income required to buy industrially manufactured consumer goods;

- farm households are based on ownership and both the labour of the family members and employed workers; their target is to manufacture marketable products and gain profit [1]

- other (including private farms).

\section{PEASANT AND FARM HOUSEHOLDS}

Peasant or individual (family) households include households comprising the members of a family or several families closely related to each other. The basic needs of a household include low-interest loans, available grants, tax credits, purchasing of new equipment at moderate prices and acquiring of land. The private interests of this group cover:

- stable and reasonable prices for agricultural products;

- a reliable system for the supply of materials and equipment and sale of the manufactured products;

- minimization of the sum of payable taxes;

- getting of required property and money on favourable terms;

- absolute economic independence of the family. 
- rational and effective use of the production, technical and labour potential, raised money;

- maximization of the family labour time. The labour time may also be maximised by means of the maximised (weekly and annual) labour time of the household members [2];

- satisfaction of the needs of the family, improvement of the life quality and social guarantees of its members, including in the field of education.

Farm households usually consist of one or several farming households, co-operatives or partnerships. Employment of wage workers is the distinctive feature of this type of farm households. For this reason economic interests of such a household will fall into two parts: satisfaction of the needs of the farm household members; and support of the farm household operation as an economic unit. Consequently, we may study two groups of interests of household operation participants: the employer and the wage worker in "Table I".

TABLE I. REALIZATION OF INTERESTS OF FARM HOUSEHOLD MEMBERS

\begin{tabular}{|l|l|l|}
\hline $\begin{array}{c}\text { Household } \\
\text { members }\end{array}$ & \multicolumn{1}{|c|}{ Interests } & \multicolumn{1}{|c|}{ Objectives } \\
\hline Employers & $\begin{array}{l}\text { intensive use for } \\
\text { maximum income } \\
\text { generation } \\
\text { - effective work } \\
\text { - cheap workforce }\end{array}$ & $\begin{array}{l}\text { - use of the workforce } \\
\text { with minimum costs } \\
\text { - intensive use of the } \\
\text { workforce }\end{array}$ \\
\hline $\begin{array}{l}\text { Wage } \\
\text { workers }\end{array}$ & $\begin{array}{l}\text { - adequate wages } \\
\text { needs } \\
- \text { favourable working } \\
\text { conditions } \\
- \text { employment security } \\
- \text { social conditions and } \\
\text { guarantees }\end{array}$ & $\begin{array}{l}\text { - profitable sale of the } \\
\text { workforce stable income, } \\
\text { available guarantees } \\
\text { and benefits } \\
- \text { possibility of staying } \\
\text { healthy }\end{array}$ \\
\hline
\end{tabular}

Consequently, farm households will be interested in improving both their own performance and the performance of wage workers.

Institutional transformations of the Russian agricultural sector resulted in a new organizational structure of the agricultural sector whose entities unite agricultural enterprises of various forms of incorporation, peasant households, farms and private households of citizens. In the world practice a farm household means an individual family enterprise or a corporate agricultural enterprise on a private or leased land plot [3]. However this definition of the farm household does not permit to distinguish between an individual peasant (farm) household and a private farm as a representative of the individual and family sector of an agrarian economy. As business entities peasant (farm) households and private farms have common features [1]:

- Family nature of their formation. Private farms and peasant (farm) households are created and operate within a family;
- Production development fused with the household management.

- Special approach to determination of income and profitability which has been worked out by the family household. Private farms and peasant (farm) households are characterized by a more flexible and dynamic allocation of the gained income for consumption and savings;

- Special social and economic status of their owners. They are at the same time the owners, managers and workers of these households;

- Intergenerational continuity and transfer of experience.

Despite the existing similarities between these two forms of business entities at this stage of the agricultural sector development they represent institutional units that differ from each other.

Peasant (farm) households are formed under official standards and rules. Firstly, the short period of farming (since 1990s) is not enough to create a comprehensive system of informal institutions. Secondly, farming desperately needs an effective regulating infrastructure for organizational and legal matters which would include legal rules, "organizational measures, mechanisms and structures ensuring absolute observance of the rules and implementation of the planned measures" [4]. Thirdly, the small number of farmers in the country and the low level of their consolidation hinder the processes of internal integration in the farming community.

On January 1, 2018 the Russian farming sector consisted of 74486 households [5]. Their agricultural production covers 23424.482 thousand ha of private and leased land.

There are presently a large number of problems preventing the development of the farming sector. The most prominent of them are connected with outdated agricultural equipment and a lack of the infrastructure including the educational one. If there is no well-developed market infrastructure peasant (farm) households cannot become full economic units and solve problems related to the sale, storage and processing of products. We believe that another group of reasons may consist of inefficient management and marketing. "In the Soviet period country people were mostly wage workers and had so-called private farms. Those people grew accustomed to this type of farming and created their "infrastructure" of a yard, simple household equipment and so on". [6]

In our opinion, another significant constraint lies in the lack of social and insurance guarantees for the farming sector. Risk farming dominates in our country and farming is exposed to droughts, hail, rain showers and frosts in spring and summer. And finally, a critical problem is connected with the insufficiency of financial resources and imperfection of the legal framework and tax system. The shortage of own resources for seasonal procurement of fuels and lubricants, fertilizers, spare parts and other current assets requires seasonal granting of loans to these households. 
The effective development of this agricultural sector is, therefore, held back by a number of legal, social, institutional and economic problems. It is shown by the poor government support for households, a lack of available funding, financing and property resources, as well as the underdeveloped social environment.

\section{EDUCATIONAL ENVIRONMENT}

Difficult communication with the external environment is a result of specific location of households.

Availability of a limited range of forms of studying and teaching methods, given that from the point of view of synergetics educational environment is an environment formed like a system which enables interaction between subjects of the educational process and the external environment and helps to discover individual traits of the student's personality [8].

Domination of individual and distant learning forms.

Researchers single out an important particularity of educational environment as a system: the subject of the educational process (a man) is a system by themselves. So in the educational environment this subject actively studies it and this results in the mutual influence of the subject and the environment [9], [10]. In a more general sense, educational environment may be understood as "any social and cultural environment where the personality undergoes a development process which is spontaneous or organized to a particular degree" [9].

In the Russian pedagogy the notion of "environment" became popular among scientists at the beginning of the XX century. "Environment pedagogy was studied by S.T. Shatsky, social environment of a child was described in the works of P.P. Blonsky, and surrounding environment was defined by A.S. Makarenko" [9]. Russian teaches believed that the object of the educational process was not the student's personality but the conditions surrounding the student. External conditions mean interpersonal and intergroup relations, internal conditions mean the student's emotional profile, self-assessment and reflections, the valuebased perception of the world.

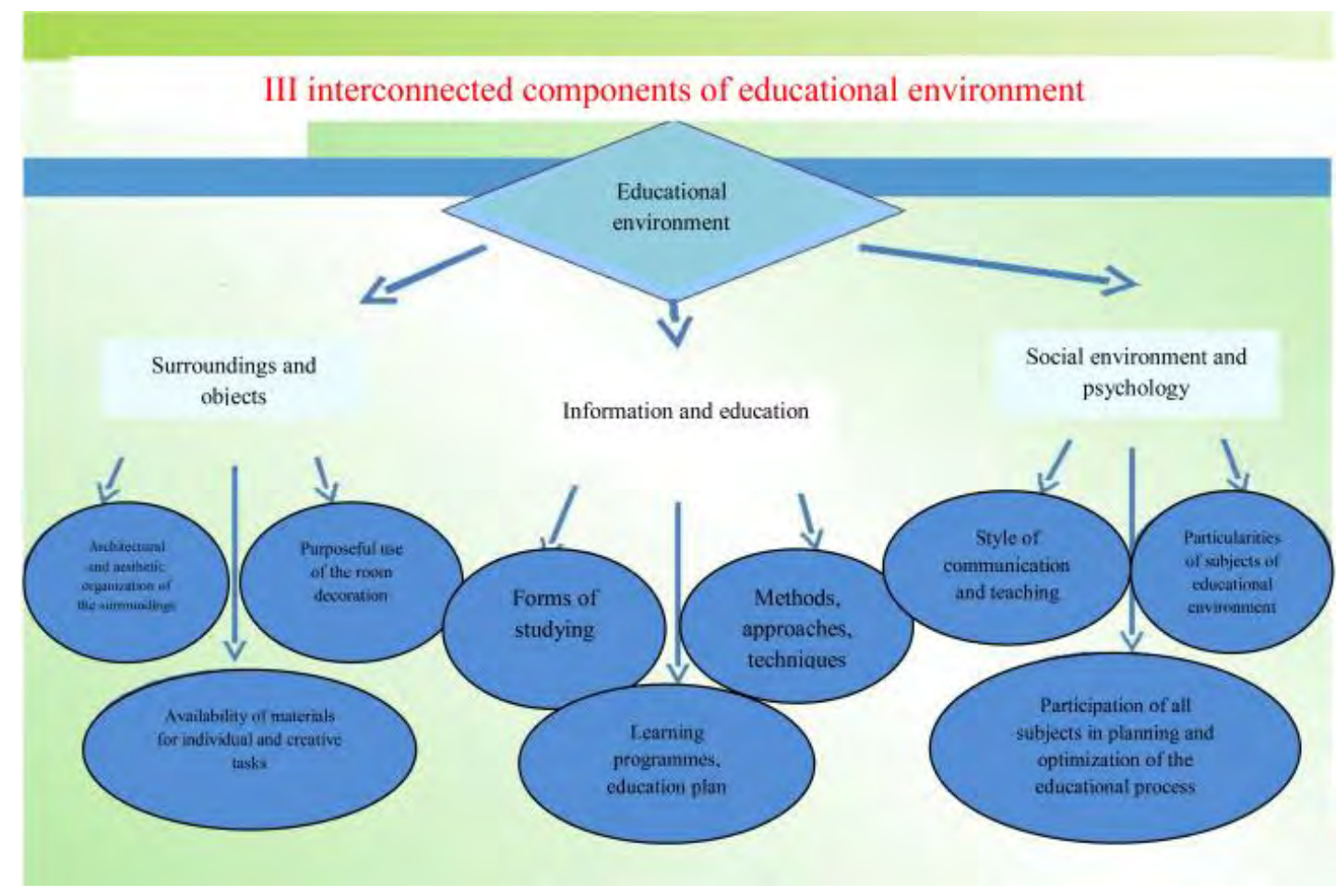

Fig. 1. Components of the educational environment.

Consequently, to develop the educational environment for households we need social and economic solutions aimed at improving the educational infrastructure according to the interests of peasant, farm and other households.

\section{CONCLUSION}

Public authorities mostly focus on supporting major agricultural producers and have no tested approaches to working with self-employed entrepreneurs. The problem of regulation tool selection for this economy sector is inseparably linked with the purposes and objectives of creating the institutional environment that corresponds to the contemporary situation [6] and where small forms of private enterprises could conduct their agricultural activities. A set of particular institutional forms constitutes an institutional system which creates certain operational conditions for players of the agricultural market and directly influences the nature and conditions of their interest realization. Institutional transformations must 
improve the existing and create new collaboration mechanisms for agricultural sector entities. Taking into account the fact that educational environment is psychological and pedagogical reality, a combination of already formed historic influences and intentionally created pedagogical conditions and circumstances aimed at moulding and developing the personality of the student [7], we may formulate some of its particularities in respect of households.

\section{REFERENCES}

[1] P.I. Dugin, "Social and economic fundamentals of the development of private farms" Federal State Educational Institution of Higher Vocational Education 'Yaroslavl State Agricultural Academy'. Yaroslavl, 2006, p. 198.

[2] A.V. Chayanov, "Peasant households: Selected works"/Editorial board of the series: L.I. Abalkin (chairman) and others. Moscow: Economy, 1985 p. 492.

[3] A.A. Barlybaev, "Social and economic nature and types of farm households in Russia//Prediction problems", 2003, No.3.

[4] A. Oleynik, Institutional Economics, Moscow: Infra-M, 200, p. 416.

[5] Russian Yearbook of Statistics, 2018: Book of Statistics/Rosstat. P76M.-2018.

[6] N.P. Gibalo, N.N. Sviridov, M.I. Skarzhinsky, V.V. Chekmarev, Institutions and Economic Relations. Monograph, Kostroma: Kostroma State University, 2003, p. 288.

[7] S.V. Tarasov, "Educational environment: notion, structure, typology" // Bulletin of Pushkin Leningrad State University, 2011, No.3.

[8] Yu.V. Ananina, V.I. Blinov, I.S. Sergeev, "Educational environment: educational environment development for secondary vocational education in the context of cluster network integration" // Moscow: AVANGLION-PRINT LLC, 2012.

[9] T.N. Shcherbakova, "On the structure of the educational environment in educational institutions" // Young Scientist, 2012, No.5.

[10] O.V. Evtikhov, "Types of educational environments in the modern education" // Modern Research of Social Problems, 2014, No. 4 (36). 